\title{
PENDIDIKAN BERKEADILAN GENDER (Belajar dari Pemikiran Emansipasi Qasim Amin) Gender Equitable based Education (Learning from the emancipation thought of Qasim Amin)
}

\section{Oleh: Sarifa Suhra*}

*Dosen di Sekolah Tinggi Agama Islam Negeri (STAIN) Watampone Kantor: Jl. HOS. Cokroaminoto Unit Pusat Studi Wanita (PSW) STAIN Watampone. Email: svarifah_suhra@:vahoo.com

\begin{abstract}
Abstrak
Islam mengakui adanya pendidikan berkeadilan gender karena pada dasarnya dalam Islam, pengetahuan adalah suci dan mencari atan menuntutnya adalah hak dan kewajiban bagi siapa saja (pria dan wanita) tanpa perbedaan. Tulisan ini mengkaji tentang pendidikan berkeadilan gender perspektif Islam menyoroti pemikiran emansipasi Qasim Amin. Qasim Amin adalah salah seorangyang consent dalam dunia pemikiran dan pembaruan Islam, melalui konsep emansipasi wanitanya ia menekankan perlunya peremption untuk mendapatkan pendidikan setara dengan laki-laki. Hal ini didasarkan pada pengembangan historistas Islam itu sendiri yang tidak menafikan peran perempuan dari waktu ke waktu. Di bidang pendidikan, dia mengatakan bahwa tertinggalnya perempuan dalam pendidikan menyebabkan tertinggalnya bangsa dari kemajuan, hal ini dikarenanakan penduduk suatu negara sekitar $50 \%$ adalah perempuan dan bagaimana mungkin perempuan bodoh dapat mendidik anak-anak mereka. Ini berarti bahwa kemajuan suatu bangsa terletak pada tingkat pendidikan warganya, khususnya perempuan karena perempuan lebih banyak waktunya untuk mendidik, melatih dan membentuk karakter anak menjadi pemimpin masa depan bangsa.
\end{abstract}

Kata Kunci: pemikiran Qasim Amin, pendidikan, berkeadilan gender

\section{Abstract}

Islam acknowledges the existence of gender-equitable education, because basically in Islam, knowledge is sacred and the search for or demanded is the right and obligation for anyone (male and female) without a difference. Qasim Amin was one of the concerns in the world of thought and renewal of Islam, through the concept of emancipation he stressed the need for women to obtain an education equal to men. It is based on historistas development of Islam itself which does not deny the role of women from time to time. In the field of education, he said the women left behind in education is lagging the nation of progress, this is because the population of a country of approximately $50 \%$ are women and how stupid women can educate their children. This means that the progress of a nation lies in the level of education of its citizens, especially women because •- omen are a lot ofplay to educate, train and shape the character of children who are future leaders of a nation.

Keywords: Thought of Qasim Amin, education, gender-just.

\section{NDAHULUAN}

ajian tentang perempuan di bcrbagai belahan dunia khususnya di Indonesia menunjukkan erkembangan yang cukup pesat. Hal itu ada mcningkatnya intensitas diskusi, seminar slitan yang menampilkan keragaman aspek :aji dan metode pendekatan yang dipakai. tu dilakukan sebagai bentuk refleksi akan esadaran berbagai kalangan akan pentingnya kedudukan dan keterlibatan perempuan dalam proses transformasi sosial.

Will Durant, seorang sejarahwan terkemuka sebagaimana dikutip oleh Marwah Daud Ibrahim, pernah menulis bahwa manusia di seluruh penjuru dunia akan menyaksikan revolusi besar mulai abad ke-20. Revolusi tersebut menurutnya bukanlah revolusi politik atau militer, tetapi kebangkitan peran perempuan di berbagai bidang kehidupan.'

Lchh lanjut dijelaskan bahwa perjuangan perempuan dalam dunia modern ini.bukan sekedar untuk mendapatkan persamaan kedudukan ".ata-mala dengan kaum laki-laki. tetapi untuk lebih dapat melakukan peranannya dalam kehidupan keluarga dan masyarakat. Dapat 
Perempuan hams melakukan otonomi terhadap dirinya sendiri, ini merupakan langkah yang hams ditempuh menuju kesetaraan dan kebebasan dari ketidakadilan. Salah satu aspek otonomi yang hams ditempuh adalah melalui "pendidikan". Pendidikan merupakan sebuah proses untuk mengembangkan potensi manusia. Pada dasarnyajiwa manusia senantiasa dinamis dan selalu bergerak aktif dalam rentang kesinambungan pada suatu titik "mengoptimalkan potensi dinamisnya". 2 Perbaikan kualitas bagi setiap manusia menjadi suatu keharusan. Pendidikan menjadi hak dan sekaligus kewajiban bagi setiap manusia untuk berubah, tidakterkecuali bagi perempuan.

Keadilan untuk mendapatkan hak dan menunaikan kewajiban adalah tujuan dalam hidup. Keadilan adalah gagasan paling sentral sekaligus tujuan tertinggi yang diajarkan setiap agama dan kemanusiaan dalam upaya meraih cita-cita manusia dalam kehidupan bersamanya. Abu Bakar al Razi (w. 865 M), menegaskan, "Tujuan tertinggi kita diciptakan dan kemana kita diarahkan bukanlah kegembiraan atas kesenangan fisik, tetapi pencapaian ilmu pengetahuan dan praktik keadilan."

Dalam konteks Islam, sentralitas ide keadilan dibuktikan melalui penyebutannya di dalam Al Quran lebih dari 50 kali dalam beragam bentuk. Disamping menggunakan kata $a l$ 'adl, kitab suci tersebut juga menggunakan kata lain yang maknanya identik dengan keadilan, seperti al-qist, al-wasat (tengah), al-mizan (seimbang), al-musawah (sama/persamaan), dan almathil (setara). Lebih dari itu keadilan menjadi nama bagi Tuhan dan tugas utama kenabian. Teks-teks suci Islam yang di dalamnya disebut kata adil atau keadilan memperlihatkan bahwa ia merupakan gabungan nilai moral dan sosial yang menunjukkan kejujuran, keseimbangan, kesetaraan, kebajikan, dan kesederhanaan. Nilai moral ini menjadi inti visi agama yang harus direalisasikan manusia dalam kapasitasnya sebagai individu, keluarga, anggota komunitasnya, maupun penyelenggara negara.

Keadilan secara umum didefinisikan sebagai "menempatkan sesuatu secara proposional" dan "memberikan hak kepada pemiliknya". Defenisi ini memperlihatkan sekaligus menunjukkan adanya keterkaitan dengan pemenuhan hak seseorang atas orang lain yang seharusya diterima tanpa diminta karena hak itu ada dan menjadi miliknya.

Salah satu wujud pemenuhan atas hak dan kewajiban setiap individu adalah pendidikan. Dalam term agama, pemenuhan kebutuhan akal dan spiritual dapat dilakukan dengan belajar untuk mendapatkan pengetahuan sebagai jalan untuk memahami agama dan membangun dunia.

Pendidikan dan menuntut ilmu dalam Islam menjadi sebuah keharusan. Dalam ayatyang pertama kali turun yaitu surat al-Alaq disebutkan kata Iqra' yang mempunyai makna membaca. Perintah ini menyiratkan pentingnya belajar melalui membaca untuk memahami semua fenomena yang ada di dunia. Nabi Muhammad SAW juga menegaskan kembali tentang kewajiban untuk mencari ilmu tanpa membedakan jender yaitu "talab al-ilmi faridatun 'ala kulli muslimun wa muslimatin"." Jadi pendidikan itu secara inklusif diperuntukkan untuk laki-laki dan perempuan. Karena pada dasarnya dalam Islam, ilmu adalah suci dan mencari ataupun menuntutnya adalah hak dan kewajiban bagi siapapun (laki-laki dan perempuan) tanpa adanya perbedaan.

Qasim Amin adalah salah seorang tokoh yang concern dalam dunia pemikiran dan pembaharuan Islam. Namun demikian, beliau juga merupakan sosok yang sangat gencar memperjuangkan nasib kaum perempuan melalui konsep emansipasinya yang salah satu aspek kajiannya adalah perlunya perempuan memperoleh pendidikan. Hal ini didasarkan pada historistas perkembangan Islam itu sendiri yang memang tidak menafikan peran perempuan dari masa ke masa. Berdasarkan paparan kerangka pikir tersebut maka kajian tentang pendidikan berkeadilan gender dalam perspektif Qasim Amin perlu dikaji dalam penelitian ini.

Berdasarkan latar belakang di atas maka rumusan masalah dalam penelitian ini adalah: 1)Bagaimanapo!a kesetaraan dalam dunia pendidikan berdasarkan Islam? 2) Bagaimana konsep pendidikan berkeadilan gender dalam perspektif Qasim Amin?

dilihal dalam bidikan lensa masa kini tampak bahwa perempuan begitu handal menekan galaksi board merekayasa gene di laboratorium. mengintip galaksi dari lensa teleskop, mengejar dan menulis berita untuk media massa. sebagian lainnya pandangan diarahkan ke manca negara. mengadu pikiran di lembaga perwakilan rakyat. merancang pesawat terbang. menjadi dokter dan sebagainya. Lihat Marwah Daud Ibrahim 1994. Teknologi Emansipasi dan Transendensi: vacana Peradaban dengan Visi Islami. .Bandung: Mizan.. h. 123

Najlah Naqiyah.2005. Otonomi Perempuan. Malang: Bayumesia Publishing. Zoes.. h. 131-132

• M. Attiyah al-Abrashi.t.t. al Tarbiyah al-lslamiyah. Mesir: Isababi al Halabi.. h, 109. 
Penelitian ini merupakan penelitian kepus- .aan (libarary research) murni. Dengan "rngkaji secara kritis terhadap buku-buku atau ?ahan-bahan yang berhubungan dengan konsep ::iikan kesetaraan. pendidikan secara umum pendidikan Islam.

Adapun data-data yang digunakan dalam xenelitian ini adalah data-data primer dan data aduuider. Data primer berwujud data lansung yang $\leadsto 7$ dari buku-buku yang ditulis oleh Qasim $1 \mathrm{~g}$ membahas tentang pentingnya kan khususnya pendidikan perempuan. data-data sekunder adalah data-data yang

- an sebagai sumber pendukung dalam yang membahas dan mengomentari -" - 'ema tersebut.

ik mengkaji pemikiran atau konsep seorang maka digunakan beberapa metode yang ">aitu:

is deduktif, yaitu dimulai dengan hal-hal - mum ke hal-hal yang khusus. Dalam Te::*ie ini digunakan dalil-dalil atau hukum umum $\boldsymbol{m} \boldsymbol{z}$ dirinci menjadi hal-hal yang kongkrit.

. induktif, yaitu dimulai dari hal-hal yang •. ke hal-hal yang umum. Dalam metode ini Sfuiiakan situasi yang kongkrit untuk menuju -i>] abstrak. Induksi-deduksi terhadap karya$\mathrm{r}>i$ tokoh, yaitu dengan mempelajarinya sebagai :: kasus (case study) dengan membuat analisis atgenai semua konsep pokok satu persatu dan

L I hubungannya agar dibangun sebuah - :esa. Melalui deduksi maka dapat diambil visi n $p$. . a umum yang berlaku bagi tokoh itu untuk ir-ami semua detail-detail pemikirannya tanpa - zan objektivitas.

aaelrtian kepustakaan (library research) ini aakan landasan filosofinya kualitatif $\therefore$. " Tahapan-tahapan yang dilakukan adalah ian mengkaji secara kritis sumber data atau a berkaitan dengan pendidikan Islam, rerumuskan perhatian terhadap konsep-..iii pembebasan. Hal ini dilkukan irapan akan diperoleh informasi yang lengkap

\section{HASIL PENELITIAN}

\section{Pola Kesetaraan Dalam Dunia Pendidikan Berdasarkan Islam}

Islam mengajarkan kewajiban dan hak menuntut ilmu berlaku untuk semua orang tanpa pengecualian termasuk bagi perempuan. Ilmu adalah suci dan menuntutnya adalah sebuah kewajiban. ${ }^{5}$ Hal ini ditegaskan oleh nabi SAW yang artinya sebabagi berikut:

"Mencari ilmu adalah kewajiban bagi setiap orang Islam, baik laki-laki maupun perempuan ".

Kesetaraan pendidikan bagi perempuan perspektif Islam mendapatkan legitimasi historis dalam sejarah keterlibatan perempuan Arab era jahiliyah dalam pendidikan. Hal ini dibuktikan dengan adanya beberapa perempuan yang sudah berprofesi sebagai penulis dan penyair. ${ }^{6}$ Ketika Islam datang kehidupan intelektual bagi perempuan (muslimah) justru tumbuh pesat dan mereka mendapatkan hak-haknya dalam masyarakat. Dalam konteks historis masa kegemilangan Islam, perempuanperempuan yang sudah "melek huruf' diantaranya adalah Hafsah (istri nabi SAW), Asiyah binti Sa'd dan Aisyah binti Abu Bakar. Perempuan-perempuan muslimah yang cerdas dan profesional dalam bidang sastra sebagai kategori penyair dan kritikus sastra diantaranya adalah Khansa', Sakinah binti Husain R.A dan Aisyah binti Tholhah (kritikus sastra).

Dalam buku-buku berbahasa arab telah ditulis beberapa nama perempuan muslimah yang professional di bidang agama, sastra, kedokteran dan seni dari masa-kemasa diantaranya: (1) Aliyah binti Al-Mahdi (penyair) (2) Aisyah binti Ahmad bin Qodim (penyair), (3) Wiladah binti Al Mustaqli Billah (penyair), (4) Lubna (penyair), (5) Fadhil ( seniwati dan sastrawan), (6) Zainab; dokter Bani Aud di bidang mata, (7) beberapa perempuan yang berkiprah dalam penyelematan nyawa dalam peperangan, (8) Umayyah binti Qois AlGhofariyah dan Al-Rabi binti Maudz (telibat dalam perang nabi SAW) (9) Ummul Hasan binti Al-Qhodi abi Ja'far Attonjali.

Data historis para perempuan terdidik tersebut, memberikan legitimasi atas seruan nabi tentang pentingnya pendidikan bagi laki-laki dan perempuan.

\& Ahmad Chads Zubair.1990. Melodologi Penelitian Filsafat .Yogyakarta: Kanisius., h. 64.

-Abrashi. op.cil.. h. 109 
Sejarah memberikan fakta-fakta perempuan memiliki peran yang mewarnai berbagai dimensi kehidupan. Dengan demikian, profesionalitas tidak bergantung dari sudutjenis kelamin tetapi ditcntukan oleli kemampuan setiap individu. Berdasarkan kenyataan sejarah tersebut maka perempuan (musliimah.) tidak hanya cukup dengan belajar secara teoritis saja, namun harus mampu memanfaatkan dan mengaplikasikan dalam bidang kehidupan sebagai seorang yang profesional.

Pengakuan Islam atas hak perempuan dalam mengenyam pendidikan yang tiada batas. Ada kebebasan bagi peremuan untuk belajar dari mulai pendidikan dasar sampai pendidikan tinggi, sesuai minat masingmasing individu perempuan. Pada dasarnya ruh pendidikan Islam adalah "kebebasan dan demokrasi*' yang tidak memandangjenis kelamin. Dengan asumsi bahwa setiap manusia (perempuan/laki-laki) mempunyai potensi yang harus diasah melalui pendidikan agar bermanfaat untuk membangun dunianya.

Perempuan harus membekali diri dengan ilmu sebagai pembuka cakrawala dan akhlak yang baik. Kesetaran antara laki-laki dan perempuan dapat dilihat dari kemampuan dan ilmu pengetahuan yang dimiliki.? Hal ini menunjukkan eksistensi seseorang. Peran pendidik perempuan dapat dimulai dari keluarga. Karena keluarga merupakan sekolah pertama bagi anak dan sekaligus tempat menimba ilmu, akhlak dan berbagai kecakapan hidup lainnya sebelum bersentuhan dengan dunia luar. Untuk mengokohkan kontribus

perempuan dalam pendidikan dapat dilihat dani syailiir IE(ioi?.5sJoiqiincv frsmi^um nBuqmaiaq BrriBn BQFISDAA sebagai benkut:

nso ma?, fuib miivAobvA jnl?.£z, ${ }_{\text {¿ }} \mathrm{BffiEgB}$ gnfibid id Ibu adalah sekolah jika engkauVmempetsimpn

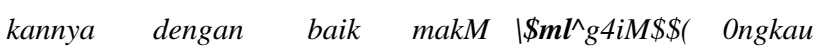
telah mempersiapkan pemuda baik lagi tangguh tyynusa depanr :• ijsv/inaa ) lirlbBl (£), (-iiB'/n9q)

Pendidikan merupakan vvahana peniberdayaari masyarakat dengan mengutamakali peilciptaan dan pemeliharah sumber yang berpengaruh, sepe'ra keluarga, sekolah, media massa, dan dunia usaha. Prinsip pemberdayaan masyarakat dengan segenap institusi sosial yang ada di dalamnya, Terutama institusi yang dilekatkan I dengan fungsi mendidik generasi griEtnai idfiri nsuide ?.B.ts $\mathrm{i}^{\wedge} \mathrm{Bmiligal}$ riBjInadmarn .iiBuqrimaq fp,' - I ii_e o >."

Muhammad 'Attiyah al-Abrashi, op.cit: t.t 1969, h. 115.

" Ibid.

"Lihat Qasim Amin.1993. Tahrir al-Mar.ah. (Kairo. AL-Hai'ah al- Mishriyyah al-Ammah li al-Kitab, 1993), h.7

"' Tim Penulis IAIN Syafif Hidayatullah. 1992. Ensiklopedi Islam Indonesia (Get VI; Jakarta: Djambatan., h.785 •- •.*< n

" Qasim Amin, op.cit., h.24

Tim penulis IAIN Syarif Hidayatullah. op.cit., h.786 penerus bangsa. Seperti: kpluarga, sekolah,! dan berbagai wadah organisasi pemuda, diberdayakan untuk dapat mengembangkan fungsi pendidikan denga baiksertamenjadi bagianyangterpadu dari pendidikan. Prinsip kemandirian dalam pendidikan dan prisnsip pemeratan menurut warga negara secara individual maupun kolektif untuk memiliki kemampuan bersaing dan sekaligus kemampuan bekerja sama. Islair. memberikan hakkepada perempuan dalam pendidika: sebagai wujud untuk kemandirian, demokrasi dan

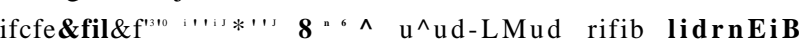
B/fisnilroq 2 r 1 BJn31 KEriBdrnarn 3 nEV nifnA Konsep Pendidikan Berkeadilan Gender Menurut

Qasim Amin $\left.r\right|_{\mathrm{B}} \mid \mathrm{BbE} v \mathrm{jbnu} / \mathrm{b} * \mathrm{BtBb}-\mathrm{Bteb}$ nuqsbA

fr:13' Qasim Amin dilahirkan di Iskandariyah Mesir pada bulan Desember Tahun 1863.' Dalam ensiklopedi. Islam Indonesia disebutkan bahwa beliau dilahirkan pada tahun $1865 .{ }^{\circ}$ Ayahnya adalah keturunan Turki dan ibunya berdarah Mesir. Idenya yang palmmenonjol adalah gagasan emansipasinyayang berawal ketika beliau mengikuti pendidikan di Prancis. Beliau melihat perempuan-perempuan Barat sangat maju. sementara bangsanya sangat jauh tertinggal dari kemajuan dan peradaban modern. Qasim Amin memandang bahwa untuk mencapai kemajuan, maka perempuan-perempuan dalam suatu negara, khususnya Mesir harus diberdayakan melalui pendidikan. $\mathrm{r}^{\wedge}$ ninggalanhijabdanpeninjauan ulangtentang institusi keluarga dan lembaga pernikahan terutama mengenai poligami dan perceraian, Pada tahun 1908 beliau meriinggal; dalam usia yang relatif muda yakni 45 tahun.' >q uUvi AoAoq Burrreg isnsgrram

${ }^{\text {гіво }}{ }^{\circ}$ lam bidang^ $\mathrm{ct}^{\wedge} \mathrm{jikan}$, ia mengatakan tertinggalnya perempuan di bidang pendidikan berarti tertinggalnya bangsa dari kemajuan, ini dikarenakan p'Snduduk suatu negeri kurang lebih $50 \%$ adalah perempuan dan bagaimana nlungkin perempuan bodoh bisa mendidik anak^anaknyaMaijqsi nBttihnsI

Qasim Amin juga merupakan orang Islam pertam, dalam sejarah yang berjuang melawan purdah. Ia keturunan Kurdi. bertugas sebagai hakim dan murid Muhammad Abduh, beliau tinggal di Kairo. Selama rnWgikuti pendidikan di Prandis, polemik-polemik riE/luyllib ini !EH .riBZEdadrnaq riE^ibibn-jq $\boldsymbol{k}$ QBDGNALgfiE/'izBrmo'ini RBLOREQIBmvAn NBQMFIRL riEgrul 'til/tajdo ri£| 
nsionaris Kristen meyakinkannnya bahwa purdah, zim'i dan perceraian adalah penyebab kelemahan Juran umat (slam. Pendidikan Prancisyang - -arr.: telali menanamkan dalam diri Qasim Amin akan amsgulan budaya Barat, dan merasa malu dan redah r -nelihat budayasendiri.'

Selama menjabat hakim, beliau menulis sebuah

ang berjudul Tahrir al-Mar'ah (emansipasi BPr «puan) pada tahun 1899. Buku ini telah -atarkan berbagai reaksi dari tokoh-tokoh intelektual iengan berbagai argumentasi yang berbeda.

dan perdebatan yang muncul kemudian momen penting dalam sejarah perempuan

- memberikan jawaban atas tanggapan dan inkjB mengenai bukunya yang pertama tersebut Mm-^-Mar 'ah). Qasim Amin kemudian menyusun ang kedua dengan judul al-mar'ah alrcrempuan modern). ${ }^{15}$ Dalam bukunya yang beliau lebih mempertegas lagi tentang . - perempuan berkiprah di ruang-ruang publik -- . ebihdahulumembekalidirinyadenganilmu nagctahuan serta meninggalkan hijab yang a hanya membatasi ruang dan gerak

\section{Etcmpuan.}

- irr buku Tahrir al-mar'ah, Qasim Amin -.: - peberapa masalah pokok yang membatasi

-...m perempuan. Beberapa masalah pokok adalah pendidikan. hijab dan reformasi - eluarga dengan perlunya ditinjau tulisan ini

- nsep pendidikan" berkeadilan gender

:' Jasim Amin. Sedangkan masalah lainnya

- t karena tidak berkaitan langsung dengan $\mathbf{t}-\mathbf{M}-$ a s a n .

r.a! Pendidikan, Qasim Amin mengklasi. menjadi tiga tingkatan secara berurutan adalah pendidikan yang wajib bagi setiap KMO. iemi menjaga kehidupannya sendiri dan untuk memenuhi kebutuhan-kebutuhan pribadinya (kebutuhan primer setiap individu). Kedua, adalah pendidikan yang bermanfaat bagi keluarganya. Ketiga, pendidikan yang bermanfaat bagi lingkungan dan masyarakat sekelilingnya. ${ }^{16}$

Munculnya pemikiran mengenai pentingnya pendidikan bagi perempuan tampaknya merupakan reaksi terhadap anggapan umura di Mesir pada saat itu, bahwa perempuan tidak perlu mengenyam pendidikan. Perempuan hanya berfungsi sebagai ibu rumah tangga saja. Bahkan mereka mempertanyakan apakah mengajarkan perempuan membaca dan menulis adalah suatu hal yang dibolehkan syara' atau malah diharamkan.

Lebih lanjut, Qasim Amin berpendapat bahwa salah satu penyebab mundurnya ummat Islam ialah karena kaum perempuan yang merupakan separuh penduduk Mesir tidak pernah memperoleh pendidikan sekolah yang mamadai. Padahal pendidikan bagi perempuan sangat perlu, karena bukan hanya untuk dirinya sendiri dan keluarganya, akan tetapi lebih dari itu untuk dapat memberikan didikan dasar bagi anakanaknya sendiri. Beliau berpendapat bahwa seorang wanita tidak mungkin mengatur urusan rumah tangganya dengan baik jika tidak dibekali dengan pendidikan, minimal dengan pendidikan dasar; agar ia dapat mengekspresikan perasaannya dan dapat berperan serta dalam masyarak kapan saja ia mau. ${ }^{18}$

Beliaujuga berpendapat bahwa satu-satunyajalan atau wadah untuk mengangkat derajat hidup ummat manusia ke tempat yang terhormat lagi mulia adalah denganjalan menguasai ilmu pengetahuan. Setiapjiwa berhak memperoleh tempat dan kedudukan mulia tersebut. ${ }^{19}$ Atas dasar itu perempuan harus dibekali berbagai macam disiplin ilmu. Selain pendidikan intelektual, mental, akhlak, juga perlu diberikan pendidikan jasmani sejak dini. Perempuan harus sehat

aryam Jameelah. 1982, Islam and Modernism, diterjemahkan oleh Ahmad .lainuri dan Syafiq al-Mughniy dengan judul Islam dan - uk Terhadap Berbagai Usaha Sekuarisasi Dunia Islam. Surabaya: Usaha Nasional., h. 187-188

$\mathrm{j}$.Ahmed. 2000. Women and Gender in Islam: Histo rical Rootsof a Modern Debate diterjemahkan oleh M.S. Nasrullah dengan mpuan dan Gender dalam Islam; Akar-akar Historis Perdebatan Modern. Jakarta: Lentera.

*Ukac Harun Nasution. 1991. Pembaharuan dalam Islam: Sejarah Pemikiran dan Gerakan. Jakarta: Bulan Bintang., h. 80

- H u t Qasim Amin.1990. al-Mar'ah al-Jadidah. Kairo: t p.. h.78

-*un Amin. op. cil.. h.3 1

32. Pendapat lain dikemukakan bahwa kaum perempuan harus menjadi pelaku utama membina keluarga agar kelak tercipta

- baik. Lihat Muhammad Thalib, 17 Alasan Membenarkan Wanita Menjadi Pemimpin dan Analisisnya (Cet.I; Bandung:

" U a ibid, h. 35 
seperti laki-laki oleh karena itu harus dibiasakan mengikuti olah raga sebagai mana perempuanperempuan Barat. Mereka tetap terpelihara dengan baik karenajasmani yang baik melahirkan keturunan yang sehat. Beliau juga berpendapat bahwa kebanyakan penyakit yang menimpa perempuan, karena tidak membiasakan diri berolahraga. ${ }^{\circ}$ Sehingga pendidikan jasmani dan kesehatanjuga sangat penting bagi kaum perempuan.

Menurut hemat penulis, Qasim Amin menempatkan pendidikan sebagai poin pertama dan utama dalam konsep emansipasi perempuannya karena ciri khas peradaban modern yang maju adalah penguasaan di bidang pengetahuan dan tekhnologi, tanpa ilmu mustahil teknologi berkembang. Di samping itu, aktivitas yang dilakukan tanpa di sertai dengan ilmu, itu akan sia-sia. Sementara berbagai jenis disiplin ilmu pengetahuan hanya bisa diperoleh melalui lembaga pendidikan.

Pendidikan merupakan suatu usaha untuk mengikis ketidak berdayaan perempuan ketika itu. Ketidakberdayaan berarti ketidak mampuan seseorang atau sekelompok orang untuk mempertahankan hakhaknya, termasuk di dalamnya kemampuan untuk berdiri sendiri dan bersaing dengan orang lain dalam kehidupan yang ia atau mereka merupakan anggotanya. Usaha pemberdayaan mestilah dimulai dengan menghilangkan hal-hal yang menyebabkan adanya ketidakberdayaan.

Ada beberapa hal yang menyebabkan ketidakmampuan atau ketidakberdayaan ini, diantaranya adalah kelemahan ekonomi. Karena kelemahan dalam bidang tersebut, maka seseorang sering kali tidak mampu mempertahankan hak-haknya. Dan tidak mampu bersaing dengan orang lain dalam merebut banyak kesempatan atau peluang. Dengan demikian orang-orang yang kuat ekonomi pada umumnya mempunyai kemungkinan yang lebih luas untuk hal yang demikian ini.

Penyebab yang lain adalah kebodohan. Aspek tersebut akan menempatkan sesorang pada posisi yang tidak mengenal dengan baik lapangan persaingan, sehingga akan kalah bersaing dengan orang-orang yang tahu dan mengenal lapangan tersebut dengan baik. Sering kalijuga bahwa orang yang bodoh tidak mengerti akan hak-haknya. Dengan demikian, tidak ada pembelaan atas hak-haknya sendiri, karena tidak pernah tahu hak-haknya yang berakibat pada tidak tahu apa yang harus dibelanya.

Demikian pula mengenai ketiadaan keberanian. sehingga sering kali membuat seseorang tidak berdaya dalam mempertahankan hak-haknya atau menolak ketidak adilan yang menimpa dirinya. Ini aspek terakhir yang memunculkan daya untuk membela hak. Sebab walaupun seseorang mempunyai banyak kekayaan dan cukup pengetahuan tapi tidak mempunyai keberanian. maka semua yang dimilikinya itu tidak menyebabkannya berdaya untuk mempertahankan hak-haknya dan menolak ketidakadilan yang menimpa dirinya.

Selain itu, ketergantungan seseorang kepada orang lain akan dengan mudah menyebabkannya tidak mempunyai daya untuk menolak ketidakadilan yang datang dari luar, terutama kalau hal itu datang dari orang yang padanya ia bergantung. Ini wajar, karena setiap daya untuk menentang tindakan seseorang yang padanya ia tergantung itu akan menyebabkannya merasa khawatir akan kehidupannya sendiri. Orang itu dapat saja memutuskan tali gantun'gannya, mana kala ia tidak suka. Padahal, tanpa tempat bergantung bagi orang yang terbiasa hidup tergantung akan kehilangan daya hidup.

Agar ummat berdaya, penyebab ketidak berdayaan itu harus di hilangkan. Namun juga harus di ingat bahwa keberdayaan bukan sesuatu yang dapat begitu saja diberikan atau didesakkan dari luar terutama dalam kaitannya dengan keberanian dan ketiadaan ketergantungan. Kekayaan dapat diberikan. pengetahuan dapat ditularkan namun keberanian dan ketidak tergantungan mesti dibangkitkan dalam diri seseorang atau kelompok orang. Oleh karena itu. pemberdayan mestilah melibatkan pembangkitan keberanian dalam diri orang yang sedang tidak berdaya itu. ${ }^{21}$

Menurut hemat penulis semua faktor penyebab ketidakberdayaan akan terkikis manakala semua kalangan berpendidikan cukup. Itu $\mathbf{1}$ ah alasannya mengapa Qasim Amin sangat getol memperjuangkan perlunya pendidikan berkeadilan gender bagi umat Islam pada umumnya dan masyakat Mesir pada

\footnotetext{
" Lihat Qasim Amin. al-Mar'ah al-Jadidah. h. 157-159.

Muslih Usa dan Aden Wijdan SZ. 1997 Pendtdkan Islam dalam Peradaban Industrial. Yogyakarta: Aditya Media, h. 54-55
} 
" = isnya yang merupakan tanah kelahirannya negeri ", amat dicintainya. Dia sangat ingin menyaksikan - ";"npuan-perempuan di negerinya maju seperti "; .puan-perempuan barat dalam hal ini perempuan :is. Lebih jauh lagi dia ingin melihat perempuantrempuan Mesir mampu berdiri di atas kaki sendiri rara menjadi parasit dalam kehidupan orang lain.

\section{- - mpulan}

gensi pendidikan terletak pada pengembangan untuk menjadi manusia yang mandiri. menjadi hak setiap orang tidak terkecuali

- rrempuan. Islam menempatkan pentingnya • •idikan bagi setiap orang sebagai hak dan

- endidikan berkeadilan gender dalam perspektif fcsrr. Amin adalah pendidikan yang merata diantara

" -a» arga bangsa bukan hanya kaum laki-laki Mesir «:i harus cerdas melainkan perempuan juga. Ia arat bahwa satu-satunya jalan atau wadah -igangkat derajat hidup umat manusia ke p.: terhormat lagi mulia adalah dengan jalan : =-_r_asai ilmu pengetahuan. Dan setiapjiwa berhak

- leh tempat dan kedudukan mulia tersebut. $\therefore$ itu perempuan harus dibekali berbagai - o n disiplin ilmu. Selain pendidikan intelektual, -etch, akhlak, juga perlu diberikan pendidikan jasmani

dmi. Perempuan harus sehat seperti laki-laki oleh harus dibiasakan mengikuti olah raga raria perempuan-perempuan Barat. Mereka tetap terpelihara dengan baik karenajasmani yang baik melahirkan keturunan yang sehat. Beliau juga berpendapat bahwa kebanyakan penyakit yang menimpa perempuan, karena tidak membiasakan diri berolahraga.

Islam melegitimasi atas hak perempuan dalam mengenyam pendidikan yang tiada batas. Pengakuan ini juga didukung oleh fakta-fakta sejarah tentang perempuan-perempuan terdidik pada masa awal. Ada kebebasan bagi perempuan untuk belajar dari mulai pendidikan dasar sampai pendidikan tinggi, sesuai minat masing-masing individu perempuan. Padadasarnya ruh pendidikan Islam adalah "kebebasan dan demokrasi" yang tidak memandangjenis kelamin. Dengan asumsi bahwa setiap manusia (perempuan/laki-laki) mempunyai potensi yang harus diasah melalui pendidikan agar bermanfaat untuk membangun dunianya. Dalam mempertegas gagasannya mengenai pentingnya pendidikan bagi perempuan, Qasim Amin sangat mengagumi profesionalitas perempuan barat dan menyeruhkan kepada semua perempuan Islam untuk mengikutinya khususnya perempuan Mesir agar bisa maju.

\section{Ucapan Terima Kasih}

Terima kasih kepada tim redaksi jurnal Litbang Kementerian Agama Makassar atas dimuatnya tulisan saya di Jurnal tersebut. Semoga Allah swt. memberikan balasan yang lebih baik. Amin ya Rabbal Alamin. 


\section{DAFTAR PUSTAKA}

al-Abrashi. M. Attiyah. t.t. al Tarbiyah al-lslamiyah, Mesir: IsaBabi al Halabi.

Amin, Qasim. 1993. Tahrir al-Mar.ah. Kairo: AL-Hai'ah alMishriyyah al-Ammah li al-Kitab.

1990. al-Mar'ah al-Jadidah, kairo: t.p.

Anton Bekker, Anton. \& Ahmad Charis Zubair.1990. Metodologi Penelitian FilsafatYogyakana: Kanisius.

Ahmed, Laila. 2000. Women and Gender in Islam; Histo rical Rootsof a Modern Debate diterjemahkan oleh M.S. Nasrullah dengan judul Perempuan dan Gender dalam Islam; Akar-akar Historis Perdebatan Modern.Cet. I; Jakarta: Lentera.

Ibrahim, Marwah Daud. 1994. Teknologi Emansipasi dan Transendensi: wacana Peradaban dengan Visi Islami, Bandung: Mizan.

Jameelah. Maryam. 1982. Islam and Modernism, diterjemahkan oleh Ahmad Jainuri dan syafiq al-Mughmy dengan judul Islam dan Modernisme; Kritik Terhadap Berbagai Usaha Sekuarisasi Dunia Islam. Cet. I; Surabaya: Usaha Nasional.

Naqiyah. Najlah. 2005. Otonomi Perempuan, Malang: Bayumesia Publishing. Zoes.

Nasution, Harun. 1991. Pembaharuan dalam Islam; Sejarah Pemikiran dan Gerakan, Cet. VIII; Jakarta: Bulan Bintang.

Tim penulis IAIN Syarif Hidayatullah.1992. Ensiklopedi Islam Indonesia,(Cet. VI; Jakarta: DJambatan.

Thalib. Muhammad. 2001. 17 Alasan Membenarkan Wanita MenjadiPemimpin dan Analisisnya. Cet.I; Bandung: Irsyad.

sa, Muslih. dan Aden Wijdan SZ.1997. Pendidkan Islam dalam Peradaban Industrial Cet.I, Yogyakarta: Aditya Media. 